\title{
Electrochemical Reduction of Nitrate on Different Cu-Zn Oxide Composite Cathodes
}

\author{
Shengxiang Yang ${ }^{1}$, Lizhang Wang ${ }^{1, *}$, Xinmei Jiao ${ }^{1}$, Peng Li $^{2}$ \\ ${ }^{1}$ School of Environment Science and Spatial Informatics, China University of Mining and \\ Technology, Xuzhou City, Jiangsu 221116, PR China; \\ ${ }^{2}$ School of Water Resource \& Environmental Engineering, East China Institute of Technology, \\ Nanchang, Jiangxi 330013, PR China \\ *E-mail: wlzh0731@126.com
}

doi: $10.20964 / 2017.05 .80$

Received: 4 January 2017 / Accepted: 17 March 2017 / Published: 12 April 2017

\begin{abstract}
The scanning electron microscope (SEM), energy dispersive spectroscopy (EDS) and X-ray diffraction (XRD) techniques were used to investigate the physic-chemical properties of the base metal cathodes of $\mathrm{Ti} / \mathrm{CuO}, \mathrm{Ti} / \mathrm{Cu}_{5} \mathrm{ZnO}_{\mathrm{x}}$ and $\mathrm{Ti} / \mathrm{CuZn}_{5} \mathrm{O}_{\mathrm{x}}$ prepared by thermal decomposition method. And the electrode performances were evaluated by linear sweep voltammetry (LSV) tests in alkaline solution and nitrate reduction by a membrane electrochemical cell. The SEM images and XRD patterns depict the prepared cathodes possess abilities of electrode area expansion and the oxide composite could be bound together with metal elements in nanoscale. The results during nitrate reduction indicate its removal relies on the potential and higher current density is beneficial to rapid nitrate conversion. In addition, the $\mathrm{Ti} / \mathrm{Cu}_{5} \mathrm{ZnO}_{\mathrm{x}}$ is superior to others two materials via its inhibition of hydrogen evolution reaction: at $20 \mathrm{~mA} / \mathrm{cm}^{2}$, the nitrate removal efficiency of $92.3 \%$ and reduction selectivity $S_{x}$ for $\mathrm{N}_{2}$ generation of $33.7 \%$ were achieved after $6 \mathrm{~h}$ electrolysis, which approximates the performances of noble metals. Moreover, the nitrate removal is highly dependent of the quantity of active sites of the cathodes and zinc could offer active sites for intermediate $\mathrm{N}$-species degradation, which could be directly confirmed by calculation of reaction rate constants through LSV tests. The mechanism is valid to for exploring possibility of high electroactivity not only on $\mathrm{Cu}-\mathrm{Zn}$ oxide composite but also on other base element modified electrodes during nitrate reduction in alkaline solution.
\end{abstract}

Keywords: Thermal decomposition; $\mathrm{Cu}-\mathrm{Zn}$ oxidize composite cathodes; Electrochemical process; Nitrate reduction

\section{$\underline{\text { FULL TEXT }}$}

(C) 2017 The Authors. Published by ESG (www.electrochemsci.org). This article is an open access article distributed under the terms and conditions of the Creative Commons Attribution license (http://creativecommons.org/licenses/by/4.0/). 